\title{
ASSESSING CANOPY COVER OVER STREETS AND SIDEWALKS IN STREET TREE POPULATIONS
}

\section{by Scott E. Maco and E. Gregory McPherson}

\begin{abstract}
Total canopy cover and canopy cover over street and sidewalk surfaces were estimated for street trees in Davis, California, U.S. Calculations were made using simple trigonometric equations based on the results of a sample inventory. Canopy cover from public trees over streets and sidewalks varied between $4 \%$ and $46 \%$ by city zone, averaging $14 \%$ citywide. Consideration of land use, planting locations, and age distribution suggests that $25 \%$ coverage of streets and sidewalks is an attainable goal for typical city zones.
\end{abstract}

Key Words. Street tree management; canopy cover; urban forest analysis.

Tree canopy cover, or more precisely, the amount and distribution of leaf area, is the driving force behind the urban forest's ability to produce benefits for the community. As canopy cover increases, so do the benefits afforded by leaf area: climate control and energy savings; improvement of air, soil, and water quality; mitigation of stormwater runoff; reduction of the greenhouse gas carbon dioxide; provision of wildlife habitat; and increased real estate value and community vitality.

The extent of community tree canopy cover is one indicator of urban forest sustainability (Clark et al. 1997). Generally, more canopy cover is presumed better. However, in terms of the fraction of ground surface covered by tree crowns, defining the ideal canopy cover in any given community has proven a difficult task because of differences in resource structure, land-use patterns, climate, management practices, and community attitudes. American Forests (2002) identified canopy cover targets by land use $(15 \%$ in downtown and industrial areas, $25 \%$ in urban residential and light commercial areas, and 50\% in suburban residential areas). Periodic canopy cover analysis can help communities assess the effectiveness of measures aimed at preserving existing trees and increasing stocking levels (Bernhardt and Swiecki 1999).

Street trees are thought to represent less than 10\% of the entire U.S. urban forest (Moll and Kollin 1993), totaling about 60 million trees (Kielbaso 1990).
Although relatively small in number, street trees are important because of their prominence along heavily used transportation corridors. Unlike vegetation found on private lands, residents pay cities to manage street trees for the benefit of the community. A positive return on this investment is contingent on maximizing net benefits (McPherson et al. 1999a) and maintaining the sustainability of these trees. Structural features of a sustainable population include adequate species and age diversity, well-adapted healthy trees, and climate-appropriate canopy cover (Clark et al. 1997; McPherson 1998).

Canopy coverage over paved surfaces has been linked to benefits as a cost-effective means of mitigating urban heat islands (Akbari et al. 1992; Asaeda et al. 1996), reducing emissions of hydrocarbons involved in ozone formation (Scott et al. 1999), control of stormwater runoff (Xiao et al. 1998), and increasing pavement longevity (McPherson et al. 1999b). Most cities, however, do not have a street tree performance ordinance that specifies a percentage of canopy cover over public streets and sidewalks as they might for other paved areas, such as parking lots. For example, a Sacramento, California, U.S., ordinance, adopted in 1983, requires parking lots to attain 50\% shading coverage of the total paved area within 15 years after development (Sacramento City Code $\$ 17.64 .030(\mathrm{H}))$. Street tree planting regulations typically require one tree per residential lot or every $10 \mathrm{~m}(33 \mathrm{ft})$ to $20 \mathrm{~m}(66 \mathrm{ft})$ of street frontage (Abbey 1998). In California, such regulations do not necessarily promote street and sidewalk shade because of a trend toward planting small-stature trees (Thompson and Ahern 2000).

Determining appropriate tree canopy cover over city streets and sidewalks is complicated because planners must consider the dynamics of stand development, as well as factors such as species composition and land use. For example, street tree stands are frequently even-aged for 20 to 60 years after planting. Canopy cover gradually increases to a maximum just 
before senescence and age-related mortality begin to reduce total cover. If trees are selectively removed and replaced over many years with similar species, canopy cover can be maintained at a sustainable level, where a prevalence of young trees is poised to fill the void left by the continued loss of old trees. Alternatively, large numbers of trees may be removed and replaced, resulting in a more drastic loss of cover and subsequent recovery. For a neighborhood stand, the amount of canopy cover achieved by first generation street trees is likely to be greater than it will be after the population has achieved a more diverse and stable age structure. Recognizing that neighborhood stands have different species compositions further complicates the issue. Therefore, the question remains-how do communities assess appropriate street tree canopy cover?

The use of photogrammetry and remote sensing are two ways cities can analyze street tree canopy cover. Calculated by ground survey or through aerial photograph examination, an alternative proposed by Bernhardt and Swiecki (1999) uses an index based on canopy cover at the edge of pavement (CCEP). While useful for comparison over time, CCEP is a one-dimensional measure of canopy cover and cannot be used to estimate benefits that are directly related to area of canopy coverage.

To calculate benefits associated with deferred street maintenance in Modesto, California, McPherson et al. (1999) assumed 50\% of street tree canopy provided direct shade over street pavement. Given the variety of street tree planting locations and typical setback distances, this assumption is likely to overestimate cover for most communities. This paper describes how a more accurate estimate can be calculated with simple trigonometry using data collected in any inventory: tree canopy diameter, planting location, and average setback distance from street or sidewalk edge.

\section{OBJECTIVE}

The objective of this study was to demonstrate a simple and efficient way to quantify a city's total canopy cover as well as the amount of cover over public pavement and sidewalks provided by the citymanaged street tree population. Results are integral to quantifying benefits as well as providing a measure of management success and comparison with other communities.

\section{METHODS}

In 2001, a sample inventory of Davis, California, street trees was conducted using methods described by Jaenson et al. (1992). Results of this inventory estimated structural attributes of the city's street tree resource on a zone (neighborhood) basis, including estimated canopy diameter, setback from street or sidewalk edge, and planting location for each tree within the population.

Nine equations were developed to estimate canopy cover of streetside city trees for three situations: total cover, cover over public street, and cover over public street and sidewalk. Total coverage was directly estimated from tree canopy diameter, assuming the vertical crown projection was circular. The equations addressed five possible tree locations recorded in the inventory: front yard, planting strip, cutout, median, and other. Average street and planting space dimensions were obtained from city staff and field checked (Cordrey 2001) (Table 1). All trees were assumed to be planted on-center in cutout, planting strip, and median locations. Because median trees were typically found only on large arterial streets where crowns did not intercept sidewalks, they were assumed to not provide sidewalk coverage. Front yard and "other" tree locations were treated the same in respective calculations.

Table 1. Typical street tree growth space dimensions and tree setback distances from back edge of street or sidewalk in Davis, California.

\begin{tabular}{lrr}
\hline Growth space & Area width & Setback \\
\hline Front yard & $\mathrm{NA}^{*}$ & $2.3 \mathrm{~m}(7.5 \mathrm{ft})$ \\
Median & $3.7 \mathrm{~m}(12 \mathrm{ft})$ & $\mathrm{NA}$ \\
Sidewalk & $1.2 \mathrm{~m}(4 \mathrm{ft})$ & $\mathrm{NA}$ \\
Cutout (square area) & $1.2 \mathrm{~m}(4 \mathrm{ft})$ & $0.6 \mathrm{~m}(2 \mathrm{ft})$ \\
Planting strip & $1.2 \mathrm{~m}(4 \mathrm{ft})$ & $\mathrm{NA}$ \\
\hline
\end{tabular}

*NA $=$ not applicable.

Total city street length was estimated to be $240 \mathrm{~km}$ (148.9 mi), at an average of $10.7 \mathrm{~m} \mathrm{(35} \mathrm{ft)} \mathrm{in} \mathrm{width.}$ Therefore, street area was 256 ha $(634 \mathrm{ac})$ or $10.4 \%$ of the city's land area. City sidewalks were typically $1.2 \mathrm{~m}$ $(4 \mathrm{ft})$ in width and increased the publicly maintained impervious surfaces by about 58 ha $(140 \mathrm{ac})$ citywide, or an additional $2.4 \%$ of total land area.

The nine equations used to estimate canopy cover were as follows: 
Equation 1

$$
\begin{aligned}
& \left.\mathrm{CC} \mathrm{m}^{2} \text { (front yard trees over street }\right)=\frac{r^{2}}{2}\left(\frac{\pi \theta}{180}-\sin \theta\right) \\
& \text { where } \theta=2\left(\arccos \left(\frac{3.5052 \mathrm{~m}}{r}\right)\right), r=\text { crown radius } \geq 3.75 \mathrm{~m}
\end{aligned}
$$

Equation 2

$\mathrm{CC} \mathrm{m}^{2}$ (front yard trees over street \& sidewalk $)=\frac{r^{2}}{2}\left(\frac{\pi \theta}{180}-\sin \theta\right)$

where $\theta=2\left(\arccos \left(\frac{2.286 \mathrm{~m}}{r}\right)\right), r=$ crown radius $\geq 2.5 \mathrm{~m}$

Equation 3

$$
\begin{aligned}
& \mathrm{CC} \mathrm{m}^{2}(\text { median trees over street })=2\left(\frac{r^{2}}{2}\left(\frac{\pi \theta}{180}-\sin \theta\right)\right) \\
& \text { where } \theta=2\left(\arccos \left(\frac{1.829 \mathrm{~m}}{r}\right)\right), r=\text { crown radius } \geq 2 \mathrm{~m}
\end{aligned}
$$

Equation 4

$$
\begin{aligned}
& \mathrm{CC}^{2} \text { (cutout trees over street) }=\frac{r^{2}}{2}\left(\frac{\pi \theta}{180}-\sin \theta\right) \\
& \text { where } \theta=2\left(\arccos \left(\frac{1.219 \mathrm{~m}}{r}\right)\right), r=\text { crown radius } \geq 1.25 \mathrm{~m}
\end{aligned}
$$

Equation 5

$$
\begin{gathered}
\left.\mathrm{CC} \mathrm{m}^{2} \text { (cutout trees over street } \& \text { sidewalk }\right)=\left(\pi r^{2}-1.486 \mathrm{~m}^{2}\right)-\frac{r^{2}}{2}\left(\frac{\pi \theta}{180}-\sin \theta\right) \\
\text { where } \theta=2\left(\arccos \left(\frac{1.219 \mathrm{~m}}{r}\right)\right), r=\text { crown radius } \geq 1.25 \mathrm{~m}
\end{gathered}
$$

Equation 6

$\mathrm{CC} \mathrm{m}{ }^{2}$ (cutout trees over street \& sidewalk) $=\left(\pi r^{2}-1.486 \mathrm{~m}^{2}\right)$

where $r=$ crown radius $=1 \mathrm{~m}$

Equation 7

$$
\begin{array}{r}
\left.\mathrm{CC} \mathrm{m}^{2} \text { (cutout trees over street } \& \text { sidewalk }\right)=4 * \frac{r^{2}}{2}\left(\frac{\pi \theta}{180}-\sin \theta\right) \\
\text { where } \theta=2\left(\arccos \left(\frac{0.6096 \mathrm{~m}}{r}\right)\right), r=\text { crown radius } \geq 0.75 \mathrm{~m}
\end{array}
$$




\section{Equation 8}

$$
\begin{aligned}
& \left.\mathrm{CC}^{2} \text { (planting strip trees over street }\right)=\frac{r^{2}}{2}\left(\frac{\pi \theta}{180}-\sin \theta\right) \\
& \text { where } \theta=2\left(\arccos \left(\frac{0.6096 \mathrm{~m}}{r}\right)\right), r=\text { crown radius } \geq 0.75 \mathrm{~m}
\end{aligned}
$$

Equation 9

$$
\begin{aligned}
\left.\mathrm{CC}^{2} \text { (planting strip trees over street } \& \text { sidewalk }\right)=C-((C-(2 A))+B) \\
\text { where } A=\frac{r^{2}}{2}\left(\frac{\pi \theta}{180}-\sin \theta\right) \text { and } \theta=2\left(\arccos \left(\frac{0.6096 \mathrm{~m}}{r}\right)\right), r=\text { crown radius } \geq 0.75 \mathrm{~m} \\
B=\frac{r^{2}}{2}\left(\frac{\pi \theta}{180}-\sin \theta\right) \text { and } \theta=2\left(\arccos \left(\frac{1.8288 \mathrm{~m}}{r}\right)\right), r=\text { crown radius } \geq 2 \mathrm{~m} \\
C=\pi r^{2}
\end{aligned}
$$

Where crown radii $(r)$ fell below specified values, cover $\left(\mathrm{m}^{2}\right)=0$, for all equations.

\section{RESULTS}

City-maintained street trees provided approximately $5 \%$ total coverage over the city's $24.55 \mathrm{~km}^{2}\left(9.48 \mathrm{mi}^{2}\right)$ land area.Varying from $4 \%$ to $46 \%$ by zone, city street trees averaged nearly $14 \%$ coverage of streets and sidewalks (Figure 1). Taking into account planting location, we estimated that $23 \%$ of all public street tree canopy cover was directly over city streets. As a result, public trees averaged $11 \%$ cover over street area citywide, but were over $40 \%$ in older, city-center neighborhoods (i.e., zone 5).

Public street trees provided much better coverage over sidewalks than streets; $24 \%$ of all sidewalk area, citywide, had direct coverage from public trees, and the average canopy projected $34 \%$ of its coverage over streets and sidewalks together. City zones with young populations had accordingly low sidewalk coverage (e.g., $7 \%$ in zone $10)$, while older city center neighborhoods averaged $60 \%$ (zone 5) to 100\% (zone 6) sidewalk coverage.

\section{DISCUSSION}

City zones with relatively high percentages of canopy cover over streets and sidewalks were those in the downtown and central Davis neighborhoods (i.e., zone segments 5 and 6). These older neighborhoods also had the greatest numbers of mature trees and the fewest numbers of available planting spaces $(<1 \%)$ compared to other neighborhoods. Therefore, canopy cover in these zones indicated what might constitute maximum levels of attainment for the community. However, zone 6 should not be used as the basis for understanding the ideal coverage for the rest of the city because of its atypical land-use regime and predominant planting locations (i.e., commercial land-use and planting strip/ cutout planting locations).

Zone 5 had $46 \%$ coverage and was more representative of the remaining nine zones by virtue of its predominately residential land use with trees planted in front yards. The street tree canopy of this zone was dominated by large, mature shade trees planted 40 to 60 years ago. The most abundant species, such as Chinese hackberry (Celtis sinensis), had begun to be removed and replaced due to disease and declining health. Therefore, the $46 \%$ canopy cover in this zone suggested that $50 \%$ was an appropriate target for a first-generation planting given the local standard of one street tree per residential lot. It appeared to be the maximum, achievable amount of canopy cover by street trees in most Davis neighborhoods (Figure 2). The optimal canopy cover for older neighborhood stands-with more diverse age structures than zone 5-would be lower than 50\% but be more sustainable over time.

Richards (1982/1983) proposed an "ideal" diameter distribution for street trees based on observations 


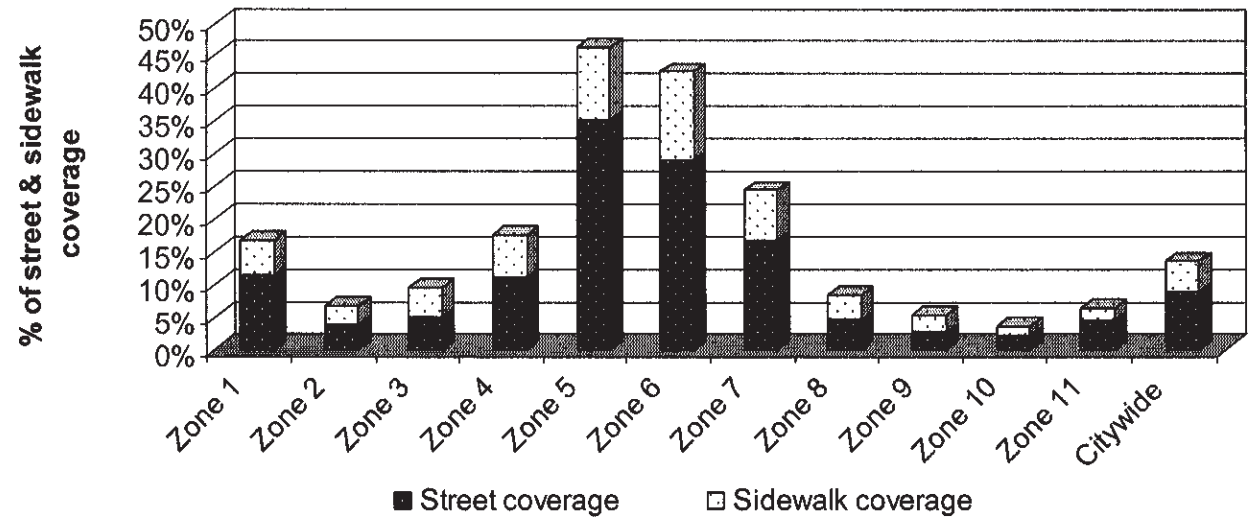

Zone 1 Mixed-age residential zone with majority of development occurring in the 1960s-1970s and to a lesser degree in the 1990s.

Zone 2 Developed within the past 20 years, this residential zone has a low species diversity and relatively few large-stature trees.

Zone 3 This zone was developed in the 1960s and has only $18 \%$ of its trees classified as large-stature deciduous.

Zone 4 Dominated by a senescing population of Japanese pagoda (Saphora japonica) trees planted approximately 40 years ago.

Zone 5 A 1950s neighborhood dominated by mature, large-stature deciduous trees and containing few available planting spaces.

Zone 6 Downtown Davis, where a mix of large- and medium-stature trees dominate and all available planting spaces are filled.

Zone 7 An older neighborhood where the senescing tree population has seen significant removal and replacement plantings.

Zone 8 Developed in the 1960s, this zone has a diverse mix of tree types and ages.

Zone 9 A 1960s neighborhood with recent commercialization, redevelopment, and street tree plantings.

Zone 10 Davis's newest neighborhood, where trees are less than 5 years old and available planting sites are prevalent.

Zone 11 This zone has $70 \%$ of its trees classified as young, and the small-stature ornamental pear (Pyrus calleryana) dominates.

Figure 1. Public street tree canopy cover as a percentage of total public street and sidewalk area.

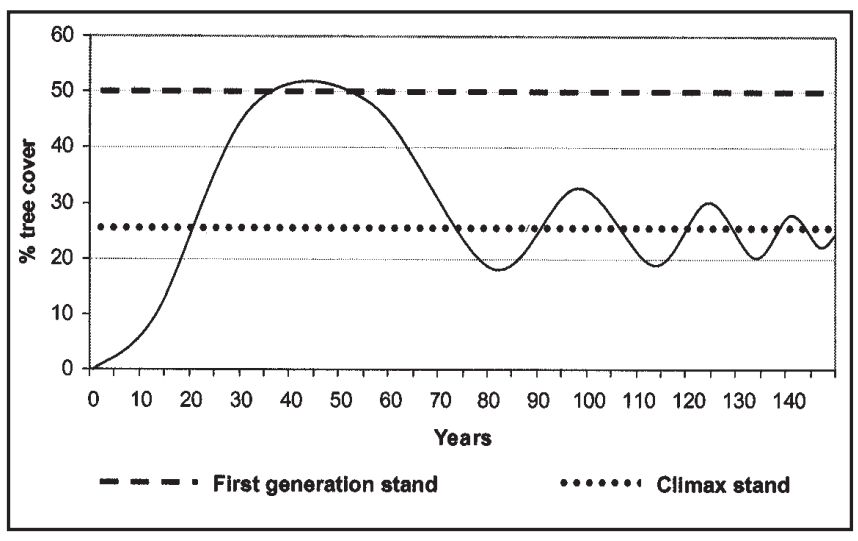

Figure 2. A model of attainable coverage over paved surfaces demonstrates how maximum canopy cover by street trees varies over time, as the relatively uniform first generation planting is transformed into a more complex, climax stand. In Davis, California, the first generation maximum cover $(50 \%)$ is reduced by half during this transition. of well-adapted trees in Syracuse, New York. This distribution suggests the largest fraction of trees $(40 \%$ of the total) should be young with diameters less than $20 \mathrm{~cm}$ (8 in.), while only $10 \%$ should be in the largest diameter class $[>60 \mathrm{~cm}$ (24 in.)]. Assuming an age structure that mimics Richard's (1982/1983) "ideal" distribution of street trees among four dbh classes, we estimated what the optimal canopy cover level was for zone 5 (Figure 3).

Accounting for the average setback, a typical young Davis, California, street tree $<20 \mathrm{~cm}$ (8 in.) had a crown diameter of $3.16 \mathrm{~m}(\sim 10 \mathrm{ft})$ and did not cover street or sidewalk surfaces. Trees that fell into Richard's (1982/1983) early functional $(20$ to $40 \mathrm{~cm})$, functionally mature (40 to $60 \mathrm{~cm}$ ), and older $(>60$ $\mathrm{cm})$ tree classes averaged coverage of approximately $10 \mathrm{~m}^{2}\left(108 \mathrm{ft}^{2}\right), 26 \mathrm{~m}^{2}\left(280 \mathrm{ft}^{2}\right)$, and $50 \mathrm{~m}^{2}\left(538 \mathrm{ft}^{2}\right)$, respectively. Street and sidewalk canopy cover dropped to $24 \%$ when adjusted to reflect Richard's (1982/1983) preferred age distribution and weighting 


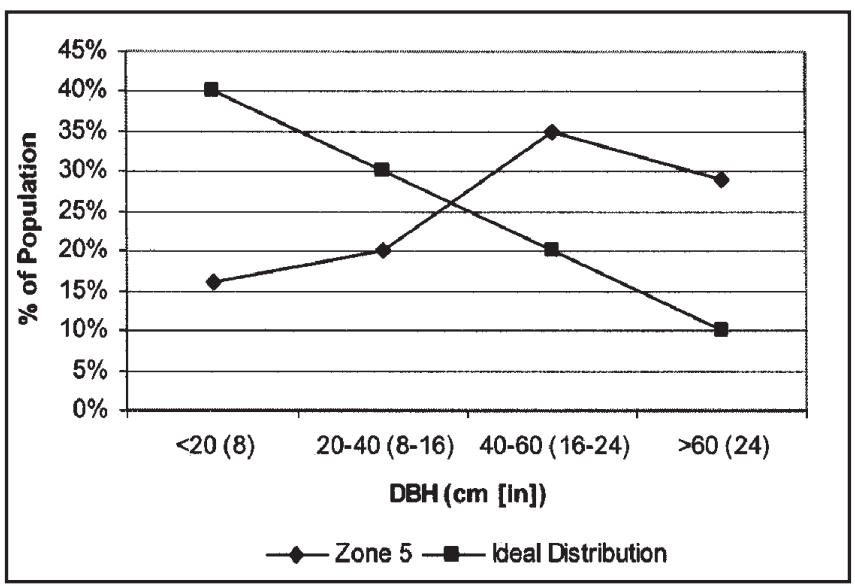

Figure 3. Relative age distribution of public trees in zone 5 and an "ideal" distribution (Richards $1982 / 1983$ ).

canopy coverage based on the above values. This estimate suggests that 25\% tree canopy cover is an appropriate target for Davis street and sidewalk surfaces that are transitioning into stands with more diverse age structure than first-generation plantings (Figure 2).

\section{CONCLUSION}

Due to the dynamic nature of street tree stands, establishing optimal canopy cover targets is problematic. The technique described here uses sample inventory data and simple calculations to assess the current level of street tree canopy cover over streets and sidewalks. Fifty percent canopy coverage appears to be an appropriate target for first-generation plantings in Davis's residential neighborhoods. However, a target of $25 \%$ is more reasonable for climax stands where tree removals and replacement plantings have reached dynamic equilibrium. Such stands benefit from a complex age structure that results in a persistent flow of benefits.

This approach to canopy cover analysis is a firstapproximation-facilitating communities' needs to understand their street tree canopy cover and determine its appropriateness. It is intended as a starting point for managers who wish to make informed decisions regarding the service provided by their street tree resource. As such, it should be understood that precision in the calculations is compromised insofar as the calculations are limited to calculating cover, not shade. Each tree is calculated individually and sums, therefore, do count overlapping canopies. Theoretically, total cover in mature, dense stands-where many canopies over- lap-could exceed 100\% and the entire street not covered. Similarly, using average hardscape and setback dimensions may result in a loss of accuracy as the scale of analysis changes. Although these findings are specific to Davis's municipal urban forest, techniques presented here can be applied in other communities to conduct this type of analysis.

\section{LITERATURE CITED}

Abbey, B. 1998. U.S. Landscape Ordinances: An Annotated Reference Handbook. John Wiley \& Sons, Inc., New York, NY.

Akbari, H., Davis, S., Dorsano, S., Huang, J., and S. Winnet (Eds.). 1992. Cooling Our Communities: A Guidebook on Tree Planting and Light-Colored Surfacing. US Environmental Protection Agency, Washington, DC.

American Forests. 2002. Urban Sprawl Information. http://www.americanforests.org/resources/sprawl/ (accessed 4/22/02).

Asaeda, T.,V. Ca, and A. Wake. 1996. Heat storage of pavement and its effect on the lower atmosphere. Atmos. Environ. 30:413-427.

Bernhardt, E.A., and T.J. Swiecki. 1999. Guidelines for Developing and Evaluating Tree Ordinances. California Department of Forestry and Fire Protection, Urban and Community Forestry Program. Riverside, CA.

Clark, J.R., N.P. Matheny, G. Cross and V. Wake. 1997. A model of urban forest sustainability.J. Arboric. 23(1):17-30.

Cordrey, B. 2001. Parks and Open Space Supervisor, Parks and Community Services, City of Davis, CA. Personal communication, April 27, 2001.

Jaenson, R., N. Bassuk, S. Schwager, and D. Headley. 1992. A statistical method for the accurate and rapid sampling of urban street tree populations. J. Arboric. 18(4):171-183.

Kielbaso, J.J. 1990. Trends and issues in city forests. J. Arboric. 16(3):69-76.

McPherson, E.G. 1998. Structure and sustainability of Sacramento's urban forest. J. Arboric. 24(4):174-190.

McPherson, E.G., J.R. Simpson, P.J. Peper, and Q. Xiao. 1999a. Benefit-cost analysis of Modesto's municipal urban forest. J. Arboric. 25(5):235-248.

McPherson, E.G., J.R. Simpson, P.J. Peper, and Q. Xiao. 1999b. Tree Guidelines for San Joaquin Valley Communities. Local Government Commission, Sacramento, CA. 63 pp.

Moll, G., and C. Kollin. 1993. A new way to see our city forests. Am. For. 99(9-10):29-31.

Richards, N.A. 1979. Modeling survival and consequent replacement needs in a street tree population. J. Arboric. 5(11):251-255.

- 1982/1983. Diversity and stability in a street tree population. Urban Ecol. 7:159-171.

Scott, K.I., Simpson, J.R., and E.G. McPherson. 1999. Effects 
of tree cover on parking lot microclimate and vehicle emissions. J. Arboric. 25(3):129-141.

Thompson, R.P., and J.J. Ahern. 2000. The State of Urban and Community Forestry in California: Status in 1997 and Trends Since 1988, California Department of Forestry and Fire Protection, Technical Report No. 9. Urban Forest Ecosystems Institute, Cal Poly State University, San Luis Obispo, CA. 48 pp.

Xiao, Q., E.G. McPherson, J.R. Simpson, and S.L. Ustin. 1998. Rainfall interception by Sacramento's urban forest. J. Arboric. 24(4):235-244.

Résumé. Le recouvrement total des cimes ainsi que le recouvrement au-dessus des rues et des trottoirs a été estimé pour les arbres de rues de Davis en Californie. Les calculs ont été faits au moyen de simples équations trigonométriques basées sur les résultats d'un inventaire par échantillonnage. Le recouvrement des cimes des arbres publics au-dessus des rues et des trottoirs varie de 4 à $46 \%$ selon les secteurs de la ville, avec une moyenne de $14 \%$ sur l'ensemble de la ville. En prenant en compte l'utilisation du territoire, la localisation des plantations et la distribution des âges, on est amené à croire qu'un objectif de $25 \%$ de recouvrement au-dessus des rues et des trottoirs est un objectif atteignable pour des secteurs typiques de la ville.

Zusammenfassung. In Davis, California, wurde die totale Überdachung durch Baumkronen und die anteilige Kronenüberdachung über Straßen und Bürgersteigen geschätzt. Die Kalkulation entstand aus einfachen trigonometrischen Gleichungen basierend auf den Ergebnissen einer Probennahme. Die Überdachung von Straßenbäumen über Straßen und Bürgersteigen variierte zwischen 4 und $46 \%$ innerhalb der Stadt, durchschnittlich $14 \%$ stadtweit. In Anbetracht der Landnutzung, Pflanzstandorte und Altersverteilung könnte $25 \%$ Bedeckung ein erreichbares Ziel sein für typische Stadtzonen.

Resumen. Se estimó la cobertura total de copa y la cobertura sobre la calle y la acera para árboles en Davis, California. Se hicieron cálculos usando simples ecuaciones trigonométricas con base en los resultados de un muestreo. La cobertura de copa de los árboles públicos sobre las calles y aceras varió entre $4 \%$ y $46 \%$ por zona de la ciudad, promediando $14 \%$ a lo ancho de la ciudad. La consideración del uso del suelo, sitios de plantación y distribución de la edad sugieren que el $25 \%$ de cobertura de copa en calles y aceras es un objetivo interesante para zonas típicas de las ciudades. 